\title{
Congresso Nacional: devolução simbólica do mandato presidencial a João Goulart
}

PEDRO SIMON ${ }^{I}$ e RANDOLFE RODRIGUES ${ }^{I I}$

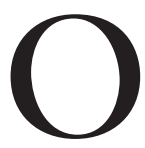
SR. PEDRO SIMON (Bloco Maioria/PMDB-RS. Pronuncia o seguinte discurso. Sem revisão do orador.) Minhas senhoras e meus senhores, vivemos hoje, realmente, um dia histórico e, diria, um dia inédito na história do Brasil. O Congresso Nacional já viveu grandes momentos de glória, de alegria, de vitória, e momentos que preferimos até esquecer. Hoje vivemos um grande momento. Eu diria que, nos meus oitenta e tantos anos, tenho diante de mim uma realidade: desta história que nós vamos analisar e viver aqui, eu participei de todos os seus passos; fui testemunha ocular de todos eles. Deus me permitiu assistir a isso hoje, o que eu nunca imaginei que haveria de acontecer.

Felicito V. Exa., Sr. Presidente do Senado, pela grandeza, pelo espírito público de realizar uma reunião como esta, e cumprimento a Sra. Presidenta da República porque, realmente, desde o primeiro momento, aceitou realizá-la. Meus filhos e meus netos, como os filhos de vocês, estudaram a História do Brasil. E a História do Brasil diz que, na madrugada do dia $1^{\circ}$ para o dia 2 de abril de 1964 , o presidente do Senado, o Sr. Auro de Moura Andrade, determinou vaga a Presidência da República porque o presidente da República estava em lugar incerto e não sabido fora do Brasil. O chefe da Casa Civil do presidente João Goulart entregou uma carta ao presidente: “O presidente da República encontra-se em Porto Alegre, na residência do comandante do III Exército, à frente das tropas legalistas". O Sr. Auro de Moura Andrade não tomou conhecimento. Deputado Federal à época, Tancredo Neves protesta aos gritos: "Sr. presidente, o número do telefone é este. Telefone para ele, e atenderá a casa residencial do comandante do III Exército; e V. Exa. falará com o presidente. Ou nos dê 3 horas e, daqui a 3 horas, o presidente estará aqui". O Sr. Auro de Moura Andrade não tomou conhecimento: decretou vaga a Presidência da República e empossou o deputado Mazzilli; e esse deputado Mazzilli integrou-se ao Ministério.

A história era realmente bem diferente. O Sr. presidente da República João Goulart estava no Rio de Janeiro. Aí se toma conhecimento de que tropas militares, sob o comando de Mourão Filho, saíram de Juiz de Fora em direção ao Rio de Janeiro. O presidente João Goulart telefonou ao seu ex-ministro da Guerra, então comandante do II Exército, Amaury Kruel, e pediu-lhe que se dirigisse a Juiz de Fora para parar as tropas. E Amaury, lamentavelmente, argu- 
mentou: "Sr. presidente, eu, desde que saí do Ministério da Guerra, não tenho a força e a autoridade que o senhor está imaginando. Se o senhor der uma declaração, der uma nota repudiando o comunismo, dizendo dos males do comunismo e de seu governo que é, eu saio em direção às tropas do Mourão, em Juiz de Fora". João Goulart, após pensar e refletir, teria dito: "Todo mundo sabe que eu não sou comunista, que o meu governo não tem nada a ver com isso, mas não posso dar essa nota, porque essa nota será recebida perante a história como um ato de covardia". Na hora, para tentar se sair melhor, fez essa acusação. Kruel, então, respondeu: "Então, eu não posso! Eu não posso ir em direção a Juiz de Fora. As tropas de São Paulo irão em direção ao Rio de Janeiro".

O presidente João Goulart veio a Brasília. De Brasília, apanhou o avião e foi a Porto Alegre. Já tinha nomeado o novo comandante do III Exército. Esse mesmo general Ladário, quando chegou a Porto Alegre, ou antes mesmo, tinha sido nomeado ministro da Guerra. Nesse meio tempo, nós estávamos em Porto Alegre, no aeroporto. Membros do antigo PTB, eu, João Caruso, Siegfried Heuser, o então deputado Leonel Brizola, estávamos todos com o general-comandante do III Exército, ministro da Guerra, à espera do Sr. João Goulart, que tinha comunicado que chegaria a Porto Alegre. A conversa já girava em torno disso: Dr. Brizola dizendo que tinha que resistir, que tínhamos que nos reunir e partir rumo ao centro para garantir o governo; o comandante do III Exército, general Ladário, mostrou, desde o primeiro momento, solidariedade e fidelidade total ao presidente da República: "Eu estou aqui para cumprir as ordens do presidente. Eu só tenho que dizer que agora não está acontecendo como na Legalidade". Naquele momento, o III Exército estava todo unido em torno da defesa do mandato. "Agora, mesmo aqui em Porto Alegre, como lá em São Leopoldo, existem focos grandes de pessoas que não aceitam. Mas eu farei" - disse o general - "o que o presidente determinar". Ficamos um tempo esperando, esperando, e o presidente chegou.

Com ele, nós nos dirigimos à casa do comandante do III Exército. Foram chegando, foram chegando, e a discussão começou. O Dr. Brizola, repito, insistindo no sentido de resistir. Pediu a Jango que designasse o general Ladário ministro da Guerra, e ele respondeu: "Ele já é ministro da Guerra. Eu já o designei”; e pediu a Jango que designasse a ele, Brizola, ministro da Fazenda. Até hoje não respondeu. E começou o debate, a discussão: "O que fazer? Como ir? Como avançar?". Foi quando surgiu, no meio da discussão, em telefonemas que o presidente Jango teve com alguém - não sei com quem, mas é quando ele veio -, o seguinte diálogo: "O que eu supunha, o que me falavam, estou vendo que é realidade".

O embaixador Lincoln Gordon relata em seu livro que a Operação Brother Sam estava em andamento e que as tropas navais, a frota naval americana já estava vindo ao Brasil com a decisão de invadir - ou melhor, não invadir; o termo era ajudar o governo constituído no Brasil - e que, naquele momento, tinha a convicção de que aconteceria aqui uma divisão como a que aconteceu 
entre Coreia do Norte e Coreia do Sul e Vietnã do Norte e Vietnã do Sul. Esse argumento foi quase que definitivo para a decisão do presidente João Goulart. O general Ladário, insistindo na sua fidelidade, disse: "Presidente, eu faço o que o senhor quiser, mas sou obrigado a dizer que as informações que eu tenho do III Exército e as que me vêm do centro do país são negativas”, e o presidente decidiu viajar para o Uruguai.

Esse foi o acontecimento, esse foi o fato enquanto aqui assumia o presidente Mazzilli. O presidente Mazzilli escolhia o seu Ministério. Não houve ato, não houve absolutamente nada. Como tantas vezes aconteceu no Brasil e pelo mundo, as forças militares se rebelaram, ganharam, depuseram o presidente e assumiram. O presidente Mazzilli designa o seu Ministério. E dizem que o que teria causado mal-estar é que, no Ministério do deputado Mazzilli, tinha mais gente do PSD e de outros partidos do que aqueles que estavam há muito tempo naquela caminhada, que era a própria UDN. Dez dias, mais ou menos, depois de Mazzilli já ter consumado o ato, de estar em pleno exercício da Presidência da República, os três ministros militares, indicados por Mazzilli, lançam um ato institucional sem número: cassações, prisões, demissões de funcionários, tudo o mais que se possa imaginar, e que nós já sabemos. Inclusive, transforma o que sobra do Congresso Nacional em colégio eleitoral para eleger o indicado por eles, o marechal Castelo Branco. Foi isso o que aconteceu. Essa foi a realidade na história do nosso Brasil.

Não estamos aqui para analisar o futuro, nem é esse o nosso objetivo, a partir das coisas que aconteceram. Só para lembrar: o presidente João Goulart foi impedido de vir ao Brasil se despedir da sua mãe quando da sua morte. Essa foi a diferença, Sra. Presidenta, entre a chegada em Brasília dos restos mortais do presidente e a sua chegada em São Borja, na sua primeira vinda, quando morto na Argentina. E, já naquela ocasião, com suspeitas ditas - eu era dirigente do partido no Rio Grande do Sul - e as hipóteses sobre onde seria enterrado. "Virá ou não virá? O que acontecerá?".

Depois de discussões, de conversas, de debates, a decisão tomada foi de que ele seria enterrado em São Borja, mas o carro entraria no Brasil pela Ponte de Uruguaiana e, de Uruguaiana, iria a São Borja sem nenhuma parada. Àquela altura, eu diria que todo o povo daquela fronteira estava ali; eu diria que lideranças do Brasil inteiro, a começar pelo Dr. Tancredo, estavam ali; e eu diria que naquela região, meus senhores, havia praticamente $50 \%$ do Exército brasileiro. Só em Santiago há cinco quarteis. E era a decisão: ter que vir, chegar e ser enterrado. Para sair de Uruguaiana e chegar ao cemitério de São Borja, era necessário passar pela catedral, não havia outro caminho. À medida que o carro ia se aproximando do centro, a multidão ia se aglomerando. Fiquei o tempo todo com o coronel, e já senti que, embora duro, ele o teria recebido. E a ele pedindo: "Mas, coronel, o que nós podemos fazer? Esse povo está aí, porque está aí, não pedimos nada. E outra coisa, coronel: repare o senhor, não há uma palavra 
de ordem. É Jango; é viva, cantando o Hino Nacional. Não tem absolutamente nada que se possa dizer. É o povo chorando, enterrando uma pessoa de que eles gostam".

Pode, não pode, foi indo. Quando chegou na catedral - a catedral estava toda fechada; eu fiquei sabendo ali -, abre-se a porta e ela estava superlotada. O povo estava lá dentro, e vieram dizer para nós que eles não deixavam enterrar Jango antes que o seu filho e a sua filha chegassem do exterior. Conversa vai, conversa vem, o coronel concordou que isso acontecesse. Não demorou muito, chegou Denise, chegou João Vicente, a D. Maria Thereza já estava lá, a sua irmã, esposa do Dr. Brizola, também já estava lá. Saiu o corpo, e o coronel determina que se vá em direção ao cemitério. São três quilômetros, talvez menos. Mas o povo pegou o caixão, arrancou-o das mãos dos soldados, e o levou. Foram caminhando. O coronel:

Não, mas a ordem que eu tenho é esta. Mas, coronel, não está acontecendo nada; eles estão levando o caixão, estão caminhando e levando o caixão. Aliás, o tempo da caminhada em que eles estão é o mesmo que se fossem de carro, porque o carro ia passar por cima das pessoas. Mas eu tenho ordem e vou executar. Ora, coronel, eu não sei quem lhe deu essa ordem. Eu só sei que, aqui, o que o senhor fizer, eu não sei o que vai acontecer. São militares, são jovens, são trabalhadores e são senhoras. E sei, coronel, que a manchete vai sair no mundo inteiro. E, no mundo inteiro, não vai aparecer o nome de quem the deu a ordem. Agora, o seu nome e a sua fotografia vão sair no mundo inteiro. Eu, com toda sinceridade, acho que o senhor... Se acontecer um incidente, eu concordo com o senhor, mas, caminhando como estão caminhando, chorando, rezando e batendo palmas...

E foi. Chegamos à beira do túmulo, eu falei em nome do Rio Grande do Sul. Não pedi licença, nem o coronel foi contra. Quando eu terminei de falar, o Dr. Tancredo me disse depois: "Pelo menos, podia ter me avisado. Eu disse: Eu falei em nome do Rio Grande. Em nome do Brasil, vai falar o Dr. Tancredo Neves". Foi uma atitude fantástica! Chegamos no dia em que a família solicitou interrogações, que existem, a um agente de segurança do Uruguai, que está preso no Brasil, em Porto Alegre, que disse que participou do complô para a morte do Dr. João Goulart. Em meio a essa questão, a Comissão da Verdade pede e consegue que os restos mortais viessem para cá. Eu felicito a ilustre Sra. Presidenta pela atitude adotada, a de receber o Dr. João Goulart com honras de Chefe de Estado. E assim foi a sua chegada a Brasília! E assim foi a sua chegada a São Borja!

O que estamos fazendo, aqui, neste momento? O Congresso Nacional - não digo por unanimidade, porque um deputado votou contra, mas o restante -, por unanimidade da decisão dos partidos, decidiu baixar uma determinação dizendo que está nula a reunião realizada pelo Congresso na madrugada do dia $1^{\circ}$ para o dia 2. [Palmas]. Singela presença! Duas linhas! Nos comentários não se entra 
em adjetivação nem em $\mathrm{A}$ nem em $\mathrm{B}$; apenas se diz o fato que ocorreu, os argumentos e os motivos que o determinaram. Aliás, aquela sessão foi interessante. Nem pro forma, nada foi colocado em votação. O presidente poderia, pelo menos, dizer: "Está em votação. Ninguém contra? Dois contra, a favor?”. Não. Ele comunicou e deu o resultado: "Está afastado o presidente”. O Congresso foi unânime, em uma sessão em que poderiam ter dito que foi assim, foi assado, alguém protestou. Pelo contrário, todos os partidos, à unanimidade, disseram que era um grande gesto, que era uma decisão realmente muito importante. Foi aprovado! Foi uma grandeza do presidente do Senado! S. Exa., por conta própria, mas representando todos nós, determinou a realização desta reunião, na qual estamos, para que S. Exa. assine e determine que a História do Brasil tenha uma página mudada.

“Consequências práticas?”, perguntou-me Collor. "Quais são as consequências práticas? Isso vai mudar a História?" Claro que não vai! Nem nós queremos mudar. Claro que não vai mudar! Mas este fato vai mudar. Os meus bisnetos vão estudar na História o que, de fato, aconteceu, e não o que os meus filhos estudaram, que foi o que não aconteceu. Eu vejo com muito carinho e com muito respeito esta decisão. Eu acho importante a maneira como se deu. Desde o início, desde que a Comissão da Verdade solicitou a revisão da possibilidade de algo ter acontecido, desde a decisão da Sra. Presidenta de dar cunho e honras de Chefe de Estado, até a decisão do Congresso. Esta, para mim...

Perdoem-me a emoção, mas é que eu vivi todos esses momentos. Eu vivi o momento de estar no aeroporto, surpreendido com aquela decisão. Eu vi quando a gente imaginava era um grupozinho. "Ah, aqui é Juiz de Fora. Qual é o contingente de Juiz de Fora?" O Mourão? Este ninguém levava a sério. Eu vivi a decisão do general Kruel, um homem de bem, respeitado, acatado e de credibilidade, amigo íntimo do presidente. Eu vivi a decisão e o drama do presidente, e as pessoas que estavam ao seu lado, quando disseram: "Ele podia salvar o seu governo". O general Kruel ia em direção a Juiz de Fora. Era só dizer que ele ia, e o Mourão vinha correndo para cá. Eu vi o fato na casa do comandante: "Vamos resistir! Vamos para a luta!".

Nós tivemos uma vitória espetacular na Legalidade. Começou no Rio Grande do Sul, ninguém levava a sério, e foi crescendo, e foi crescendo, e pelo rádio. Ele assumiu a Presidência. Eu vi a casa do ministro, quando ele foi obrigado a reconhecer que a hora era diferente. Na Legalidade, as forças da sociedade brasileira estavam uniformes. O baque que houve naquele momento foi a renúncia, até hoje inexplicável, do Sr. Jânio Quadros, mas a posse do Sr. João Goulart era aceita, por unanimidade. João Goulart foi eleito vice-presidente naquela época eram eleitos, no voto, presidente e vice-presidente -, fazendo muito mais voto do que o Sr. Juscelino Kubitschek, que era seu companheiro de chapa. Cinco anos depois, ele foi eleito de novo pelo voto, mas quem ganhou para presidente foi Jânio Quadros, seu adversário. E ele ganhou de novo. De- 
pois, criou-se o parlamentarismo e se discutiu: "Fica o parlamentarismo, e Jango deixa de ser presidente, parlamentarista?”. E Jango ganhou com 80\%. Então, ele foi eleito praticamente três vezes presidente da República.

Por isso, meus irmãos, a beleza deste movimento e o fato de ele acontecer justamente neste momento, em que o mundo vive a hora de Mandela. V. Exa., Sra. Presidenta, esteve lá e pôde ver o que o mundo sentiu na grandeza desse homem, que eu tenho para mim uma das pessoas mais fantásticas da história. Duas pessoas que eu conheci e me tocaram para o resto da vida foram Dom Hélder Câmara, arcebispo do Rio de Janeiro, que pesava uns 45 quilos e que, com aquela voz, parecia que queria mudar o mundo, e Mandela. Eu acho o exemplo de Mandela a coisa mais fantástica que eu já vi, a grandeza dele na condução daquele povo. O natural, o normal, as mortes, a tirania, os horrores que ele sofreu, era fazer justiça, dar o troco - prisão, cadeia etc. E ele, praticamente sozinho, dizendo: “Não, não, porque, se eu fizer isso, nós vamos fazer excesso também, e vai ser um círculo vicioso do qual nós não vamos sair. Vamos apurar, vamos apurar. O cara vai ser acusado, vai ser acusado. Vai reconhecer que errou, vai reconhecer; vai pedir desculpas". E terminou reunindo, no estádio, negros e brancos numa partida, abraçando-se, e deu-se essa confraternização.

Eu falo e dou esse exemplo porque, da nossa parte, é estar a par de todos. E isso que nós queremos. Eu acho que hoje, neste momento, minha Presidenta; neste momento, meu querido presidente do meu partido, Michel Temer, nós estamos realmente olhando para a frente. Nós não estamos preocupados. Não há nada aqui que queira atingir $\mathrm{A}, \mathrm{B}, \mathrm{C}$ ou $\mathrm{D}$, aqueles que podem ter feito algo e muito menos os que hoje que estão nos cargos indicados pelo próprio governo. O que há de bom, sim, é isto: nós podermos dizer que hoje se encerrou um ciclo e hoje se inicia outro. Queira Deus que tenhamos a grandeza, o respeito e o carinho de caminharmos adiante. A ti, meu querido João Vicente [Goulart]; à tua mãe, à tua esposa, a teus filhos, um abraço muito sincero. Eu fiquei fã da tua garra, da tua firmeza de ir avançar, ir adiante e viver este dia. E, Sra. Presidenta, eu digo com o maior respeito: foi um gesto muito bonito, de muita grandeza, de muito espírito público. V. Exa. apos a sua assinatura, e a sua assinatura está dizendo: o Brasil é outro, é democrático, é libertário.

Obrigado, meus irmãos. [O orador é cumprimentado. Palmas.]

Pedro Simon é formado em Direito pela Pontifícia Universidade Católica do Rio Grande do Sul, com pós-graduação em Economia Política, sendo também especialista em Direito Penal. É senador da República (PMDB) pelo Rio Grande do Sul. @-simon@senador.gov.br

I Senado da República Federativa do Brasil, Brasília/DF. 

nuncia o seguinte discurso. Sem revisão do orador.) Minhas senhoras, meus senhores, ministros de Estado, autoridades presentes, a sessão de hoje é histórica e, permitam-me, de emoção, por inúmeras e diferentes razões. Invariavelmente, a história nos mostra que, quando se esquecem dos erros cometidos no passado, os povos voltam a incorrer nos mesmos erros. Este é o significado primeiro do que nós estamos aqui a fazer.

Este ano de 2013, que antecede o ano de 2014, ano do cinquentenário do golpe de 1964, vai ser marcado pelas homenagens à figura de João Belchior Marques Goulart. E aqui, Presidenta Dilma, há de se registrar, primeiro, o pedido de desculpas - é isso que tem de ser registrado - que o Estado brasileiro tem feito à figura do presidente João Goulart, à família do presidente João Goulart. Aqui há de ser registrado o que tem sido feito, primeiro, por parte do governo brasileiro, nos esforços não somente para a exumação, na busca da verdade do que ocorreu com o presidente João Goulart, mas também para recuperar as homenagens por ter sido ele o único presidente da República do nosso país que, ao morrer, não recebeu as homenagens de Chefe de Estado, e por ter sido ele o único presidente da República da história do nosso país a falecer no exílio. A essas homenagens que o governo brasileiro prestou, se juntaram e se consolidam aqui, no dia de hoje, as homenagens do Parlamento brasileiro. Executivo e Legislativo se unem para prestar as devidas homenagens do Estado brasileiro ao presidente mais popular da história deste país. Aqui há de se registrar, primeiro, a história de João Goulart.

Talvez, na história pública do país, não haja alguém com uma trajetória política tão curta, mas tão celebrada, quanto a de João Goulart. Em 14 anos, João Goulart foi deputado estadual, secretário de Justiça do Estado do Rio Grande do Sul, ministro do Trabalho do governo de Getulio Vargas, vice-presidente da República eleito por duas vezes e presidente da República Federativa do Brasil. Como ministro do Trabalho do governo de Getulio Vargas, reajustou em 100\% o salário mínimo dos trabalhadores. Nunca na história nacional um ministro do Trabalho ou um agente político teve a coragem de fazer isso. Ao ser colocado num dilema, pressionado pelas elites nacionais para escolher entre elas e os trabalhadores, João Goulart não titubeou: ficou ao lado dos trabalhadores, do povo, e renunciou ao Ministério do Trabalho durante o governo de Getulio Vargas. A trajetória de João Goulart é marcada pela sua coerência, por ter estado sempre de um lado bem claro: o lado do povo brasileiro, o lado dos trabalhadores. Esta opção ficou clara e patente nos anos do exercício de sua vida pública.

Nenhum agente político, nenhum presidente da República foi tão eleito quanto João Goulart. Ele foi eleito vice-presidente de Juscelino em 1956, com 500 mil votos - meio milhão de votos a mais do que o próprio presidente da República. Foi reeleito vice-presidente da República - em uma época em que este era eleito em chapa separada do presidente da República - de Jânio Quadros 
logo em seguida, mesmo sendo seu opositor naquela eleição. Foi conduzido ao poder político em 7 de setembro de 1961, não pelo voto, mas nos braços do povo brasileiro, numa das mais memoráveis campanhas civilistas da história nacional, a campanha da Rede da Legalidade conduzida por Leonel Brizola. Como se não bastasse isso, em 1963, foi conduzido e reconduzido aos plenos poderes presidenciais por um plebiscito, com o apoio de $90 \%$ do povo brasileiro.

João Goulart, ao ser deposto dos seus poderes presidenciais em $1^{\circ}$ de abril de 1964, tinha o apoio, segundo pesquisa Ibope, de 80\% do povo deste país. Não é à toa que telegrama do embaixador norte-americano ao presidente dos Estados Unidos, do dia 2 de abril de 1964, falava do significado daquele golpe. Dizia o embaixador americano: "Sr. Presidente, os nossos aliados no Brasil sagram-se vitoriosos. No dia de hoje, na cidade de São Paulo, nossos aliados fazem a festa da vitória. Pena registrar que, na comemoração, só estão ausentes as camadas mais pobres da população". Isso porque, naquele dia, as camadas mais pobres haviam sido derrotadas - e haviam sido derrotadas porque os mais pobres estavam ao lado do João Goulart, estavam ao lado dos trabalhadores do povo.

É injustiça também dizer que aquilo que os acontecimentos do dia 31 de março e da madrugada do dia $1^{\circ}$ para o dia 2 de abril de 1964 foram orquestrados - abre aspas - somente pelas forças militares deste país. Que seja recomposta a verdade histórica: o que aconteceu de 31 de março para $1^{\circ}$ de abril de 1964 foi um golpe daqueles setores que não queriam verdadeiramente que este país avançasse. As forças que queriam que este país avançasse estavam manifestadas nos discursos de João Goulart de 13 de março de 1964. Naquele discurso, no famoso discurso da Central do Brasil, no discurso das reformas de base, estavam manifestas as aspirações para que o Brasil avançasse: as reformas de base; a reforma agrária; encampar as refinarias; a reforma educacional; erradicar o analfabetismo; as reformas progressistas para que este país fosse soberano e se desenvolvesse. As verdadeiras forças responsáveis pelo golpe de 1964 foram as forças conservadoras, as elites conservadoras nacionais, aliadas ao capital estrangeiro, aliadas verdadeiramente aos interesses do imperialismo norte-americano.

Em tom claro e alto, é bom que se diga quais foram as forças responsáveis. As primeiras grandes vítimas do golpe de 1964 foram os militares: sete mil militares foram cassados pelo golpe de 1964. Isso tem que ser dito porque é à verdade histórica que nos reportamos e é ela que tem que ser recomposta. Essa conciliação com os militares nacionais, que são defensores inclusive de nossas instituições, é necessário que seja feita para ser recomposta, inclusive, a verdadeira história. O que está sendo feito com esta resolução, no dia histórico de hoje, é especial. Não é uma resolução contra ninguém, contra nenhuma instituição; é fundamentalmente uma resolução a favor da história, a favor do Brasil, a favor, em especial, das gerações que virão.

Com a sessão que foi anulada, presidente Renan Calheiros, nesta sessão 
do Congresso Nacional, V. Exa. passa para a história como antagonista ao Sr. Auro de Moura Andrade. O Sr. Auro de Moura Andrade, na madrugada do dia $1^{\circ}$ para o dia 2 de abril de 1964, declarou vaga a Presidência da República sem consultar o Congresso Nacional; sem consultar um deputado sequer, sem consultar um senador sequer. Ou melhor: ele o fez sob o protesto de senadores, inclusive sob o protesto de um senador, como já disse o senador Pedro Simon, chamado Tancredo de Almeida Neves, que, aos gritos de "Canalha! Canalha!", protestava contra aquele ato de violência que era praticado.

A sessão do dia $1^{\circ}$ de abril de 1964, que ora nós anulamos, ocorreu sem nenhuma deliberação do Congresso Nacional. Foi feita sob a força e sob o grito do Sr. Auro de Moura Andrade, e sob o protesto de Darcy Ribeiro, chefe da Casa Civil do presidente João Goulart, que dizia ter a prova inconteste de que o presidente estava em território nacional. Naquele dia, dizia Darcy Ribeiro, em ofício que foi lido no plenário do Congresso Nacional pelo $1^{\circ}$ Secretário: "O Sr. Presidente da República incumbiu-me de comunicar a V. Exas. que, em virtude dos acontecimentos nacionais das últimas horas, para preservar do esbulho criminoso o mandato que o povo lhe concedeu e investido na posição de chefe do Poder Executivo, decidiu viajar para o Rio Grande do Sul, onde se encontra à frente das tropas militares legalistas, no pleno exercício do poder constitucional de seu ministério". Estava o presidente João Goulart em território nacional, cumprindo, ou seja, no exercício do seu poder constitucional.

As tropas legalistas, leais à Constituição, que prometeram cumprir a Constituição de 1946, sob o comando do general Ladário Teles, estavam lá em Porto Alegre, no Rio Grande do Sul, sob o comando do presidente legal do Brasil. Estava lá o presidente da República. Desconheceu isso, naquele momento, o presidente do Congresso Nacional, Auro de Moura Andrade! Desconheceu isso e, por não conhecer isso, declarou vaga naquele momento a Presidência da República. Essa sessão foi, de um só ato, ilegal e ilegítima.

O projeto de resolução que foi apresentado para anular essa sessão é a união de dois personagens, um deles o único com formação de historiador aqui do Senado, do Congresso Nacional, se me permitam dizer - talvez a minha formação de historiador se una na Câmara dos Deputados à formação do meu companheiro Chico Alencar, que também é historiador. Pois bem, a união dos dois que apresentaram este projeto de resolução é a união de um historiador e da testemunha, o meu companheiro Pedro Simon. Foi Pedro Simon testemunha dos acontecimentos de Porto Alegre. Estava ele lá, a assistir a chegada de João Goulart, os acontecimentos da residência do general Ladário Teles.

Estava ele lá, a receber o corpo de João Goulart e a assistir a resistência heroica do povo de São Borja. Quando quiseram, sob as ordens do governo, que fosse rapidamente sepultado João Goulart, no ano de 1976, foi o povo de São Borja, o carinhoso povo gaúcho, que tomou o ataúde de João Goulart pelas mãos, o sepultou e realizou o velório, a contragosto das forças do governo na- 
quele momento. Foi Pedro Simon testemunha de todos esses momentos. Esta sessão é resultado da junção testemunha e historiador para desmascarar um ato leviano, naquele momento, do Congresso Nacional, que depôs um presidente colocando em seu lugar um presidente da Câmara. Uma semana depois, seriam nomeados três novos ministros, que editaram uma sequência de atos institucionais, ilegais por excelência, inconstitucionais por excelência, que instauraram e inauguraram um período de ditadura da nossa história que não se justifica. Os povos que não recuperam a sua memória voltam a incorrer, como já disse, nos mesmos erros do passado.

Obviamente, a anulação dessa farsa do dia $1^{\circ}$ de abril de 1964 não tem efeitos práticos sobre os males praticados pela ditadura; não repara a tortura, não repara os crimes, não repara tudo o que ocorreu ao longo de intermináveis 21 anos. Mas o que a resolução traz é o simbolismo de um resgate histórico. Ao contrário do que alguns pensam, a humanidade se move pelos símbolos. Os símbolos nos unem, os símbolos nos dividem. Por alguma razão, os símbolos representam algo mais do que significativo na história humana. Milhões de britânicos fazem um minuto de silêncio, às 11 horas, todo dia 11 de novembro. É uma homenagem aos 886 mil soldados do Reino Unido que tombaram na Primeira Guerra Mundial. Às $8 \mathrm{~h} 15 \mathrm{~min}$ de cada 6 de agosto, milhões de japoneses se calam por 60 segundos para lembrar o que ocorreu em Hiroshima e em Nagasaki. Da mesma forma, milhões de habitantes de Israel cessam tudo às 11 horas de cada dia 27 de janeiro para lembrar os mortos da Segunda Guerra Mundial e a libertação de Auschwitz. Não existe, nesses gestos, nessas manifestações, nenhuma intenção demagógica, nenhuma atitude pirotécnica, nenhuma inutilidade prática, como poderia alguém imaginar. Nenhum britânico, nenhum japonês, nenhum judeu será ressuscitado; nenhuma dor será apagada. Do mesmo modo, com o gesto que estamos fazendo hoje, não se compensa por tudo o que passou a família Goulart.

E não foi pouco o que passou a família Goulart! João Goulart, repito, foi o único presidente a morrer fora do país e não receber honras de Chefe de Estado; a Bandeira Nacional não foi hasteada a meio-pau. As homenagens só ocorreram agora, 37 anos depois. Maria Thereza Goulart, a mais jovem e mais bela primeira-dama que este país já viu, não teve o direito de ver a sua mãe quando esta faleceu aqui, em 1969. Quando seu pai faleceu, em 1979, sequer ela teve, sob vigilância, o direito de entrar no Brasil. Poucos brasileiros talvez tenham amado tanto o Brasil quanto João Goulart, e poucos brasileiros talvez tenham sofrido tanto por amar o Brasil quanto João Goulart! Poucos brasileiros talvez tenham sofrido tanto por amar o Brasil quanto essa família tenha sofrido!

O que estamos fazendo no dia de hoje não reparará a dor dessa família, mas é um gesto, e a história é feita de gestos, a história é feita de reparação, como diz a poesia de Chico Buarque: "A História é um carro alegre / Cheio de um povo contente / Que atropela indiferente / Todo aquele que a negue". Aqueles 
que negaram a história, aqueles que romperam o ciclo rico e democrático da história nacional, de crescimento democrático próspero, o ciclo de crescimento econômico próspero dos anos 1960, pagam agora com o atropelamento da democracia. É isso o que significa.

Erra quem imagina que os símbolos são perda de tempo ou mero oportunismo político. Acertará quem acredita que pelos símbolos corretos se orienta e se eleva a consciência do mundo. Exumar a verdade não é política para os mortos; é um compromisso perene dos que defendem, em todas as épocas a vida, dos quem defendem em todas as épocas, a liberdade. O símbolo do dia de hoje é o símbolo de que a história venceu e de que a democracia jamais será apagada da memória dos povos, da memória do nosso País. [Palmas.]

Randolfe Rodrigues é formado em História pela Universidade Federal do Amapá. É senador da República (PSOL) pelo Amapá. @ - randolfe.rodrigues@senador.leg.br Discursos pronunciados no dia 8 de dezembro de 2013.

II Senado da República Federativa do Brasil, Brasília/DF. 


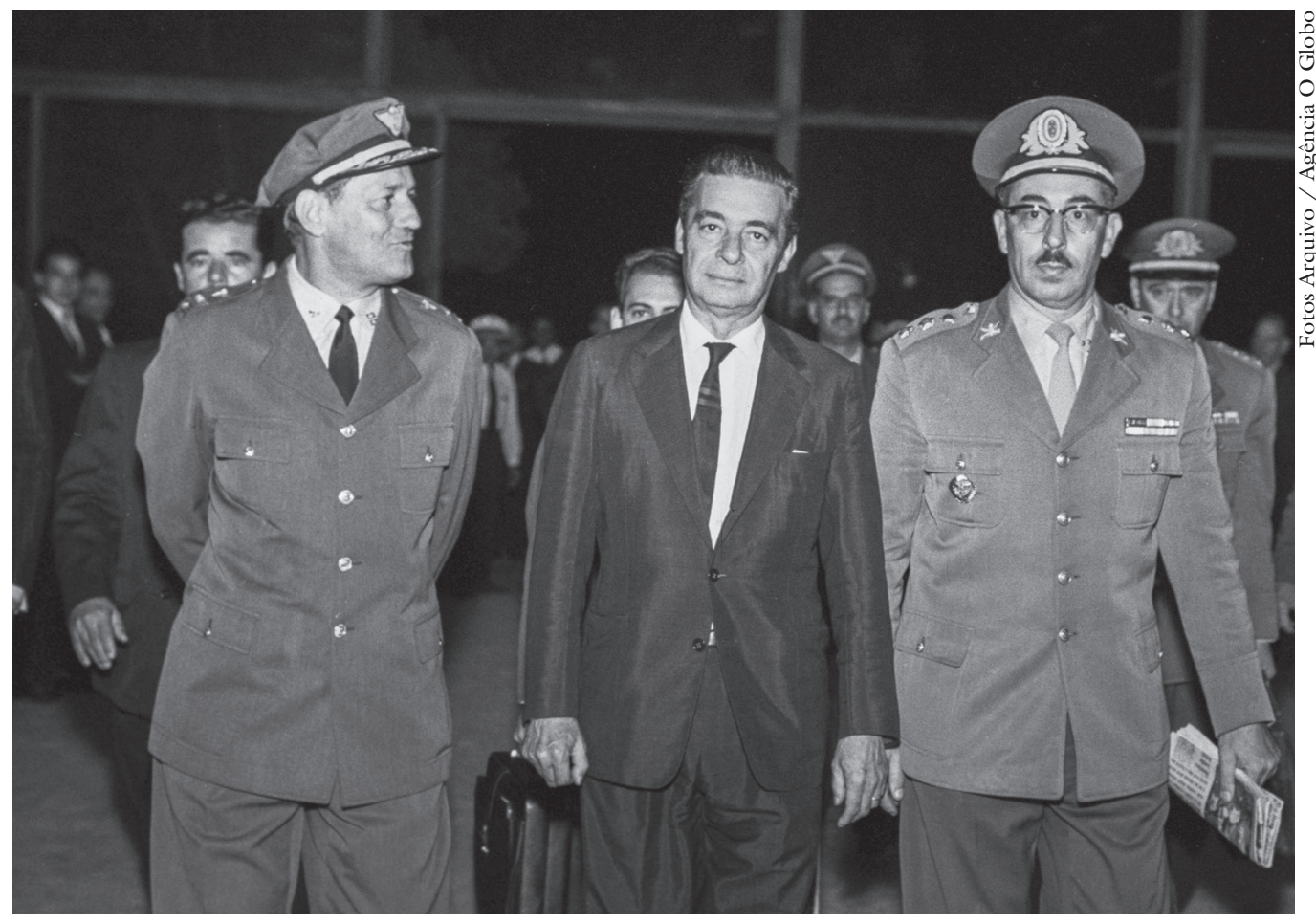

Presidindo a sessão de $1^{\circ}$ de abril de 1964, o presidente do Senado Auro Soares de Moura Andrade (Partido Social Democrático - SP) declarou vaga a Presidência da República.

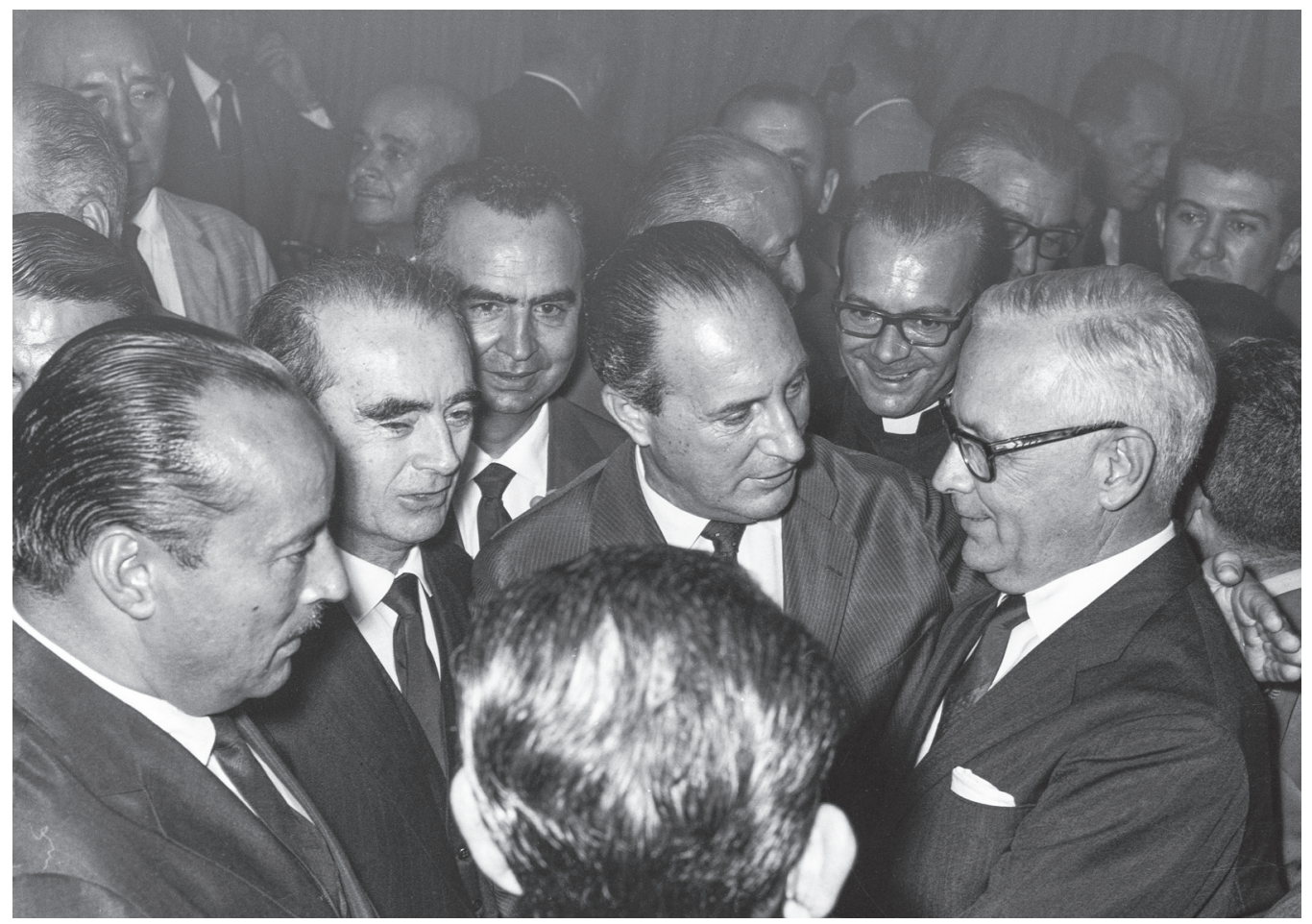

O presidente da Câmara, Ranieri Mazzilli (PSD - SP), assumiu a Presidência da República em 2 de abril de 1964 por ocasião do golpe politico-militar que depôs o presidente João Goulart. 


\section{CONGRESSO NACIONAL PROJETO DE RESOLUÇÃO № 4, DE 2013-CN}

Torna nula a declaração de vacância da Presidência da República efetuada pelo Presidente do Congresso Nacional durante a segunda sessão conjunta de 2 de abril de 1964.

O Congresso Nacional resolve:

Art. $1^{\circ}$ Declarar nula a declaração de vacância da Presidência da República exarada pelo Presidente do Congresso Nacional, Senador Auro de Moura Andrade, na segunda sessão conjunta, da quinta legislatura do Congresso Nacional, realizada em 2 de abril de 1964.

Art. $2^{\circ}$ Esta resolução entra em vigor na data da sua publicação.

\section{JUSTIFICAÇÃO}

No dia 31 de março de 1964, o Brasil viveu o início de um golpe de estado que o levaria a 21 anos de ditadura militar.

Durante todo o dia 10 de abril, o Presidente João Goulart percorreu o País na tentativa de manter a legalidade e o governo constitucional democraticamente eleito. 
Dessa forma, a bordo de um avião da Força Aérea Brasileira, Jango se deslocou do Rio de Janeiro para Brasília e, em seguida, diante da situação de cidade sitiada e na iminência de ser detido pelas forças golpistas, se dirigiu para a cidade de Porto Alegre, onde/supostamente encontraria forças aliadas.

Durante seu trajeto, na madrugada do dia 2 de abril de 1964, o então Presidente do Congresso Nacional, Senador Auro de Moura Andrade, contrariando o art. 85 da Constituição Federal de 1946, que determinava que "o Presidente e o Vice-Presidente da República não poderão ausentar-se do País sem permissão do Congresso Nacional, sob pena de perda do cargo" declarou vaga a Presidência da República, quando, na verdade, o Presidente João Goulart se encontrava em território nacional.

Em seu livro A Ditadura Envergonhada, Elio Gaspari narra da seguinte forma o referido episódio:

"Enquanto o presidente voava para o Rio Grande do Sul, Auro Moura Andrade, baseado "nos fatos e no regimento", declarou vaga a Presidência da República e organizou uma cerimônia bizarra. No meio da madrugada, acompanhado pelo presidente do Supremo Tribunal Federal, rumou para o Palácio do Planalto. Levava consigo o deputado Ranieri Mazzilli, que, como presidente da Câmara, seria sucessor de Jango, caso a presidência estivesse acéfala(...).

A posse do deputado Ranieri Mazzilli na Presidência era inconstitucional, visto que João Goulart ainda se encontrava no Brasil. Preenchia, contudo, a necessidade de um desfecho aparentemente legítimo. O Departamento de Estado Americano estava pronto para recebê-lo desde setembro de 1963. Em poucas horas a Casa Branca e a embaixada do Rio começaram a discutir o texto e a oportunidade de uma nota do presidente Lyndon Johnson reconhecendo o novo governo brasileiro (...)"

Fica claro que o ato do Presidente do Congresso Nacional, além de sabidamente inconstitucional, serviu para dar ao golpe ares de legitimidade.

Ademais, além da ilegalidade daquela sessão, convocada para um comunicado ao arrepio da Constituição e do Regimento Comum, quando a sessão foi aberta às 2 h40min da madrugada, foi solenemente ignorada a mensagem do Senhor Presidente da 
República, levada pelo seu líder, o Deputado Tancredo Neves, que informava seu deslocamento para Porto Alegre, onde estabeleceria a sede do governo:

Brasilia, 2 de abril de 1964 - Senhor Presidente, o Senhor Presidente da República incumbiu-me de comunicar a Vossa Excelência que, em virtude dos acontecimentos nacionais das últimas horas, para preservar de esbulho criminoso o mandato que o povo the conferiu, investindo-o na Chefia do Poder Executivo, decidiu viajar para o Rio Grande do Sul, onde se encontra à frente das tropas militares legalistas e no pleno exercício dos poderes constitucionais, com seu ministério. Atenciosamente, Darci Ribeiro - Chefe do Gabinete Civil.

Em poucos minutos, sem discussão, Jango foi usurpado do cargo de Presidente da República, num ato unilateral do então Presidente do Congresso Nacional, Senador Auro de Moura Andrade.

O presente projeto de resolução tem a finalidade de demonstrar que o Congresso Nacional brasileiro, passados 49 anos desse descalabro, não se mantém curvado às circunstâncias que levaram ao regime totalitário e repudia de forma veemente a importante contribuição ao golpe, dado pela então presidente desta Casa congressual.

Trata-se do resgate da história e da verdade, visando tornar clara a manobra golpista levada a cabo no plenário deste Congresso Nacional na madrugada de 2 de abril de 1964 e corrigir, ainda que tardiamente, uma vergonha histórica para o Poder Legislativo brasileiro.

Sala das Sessões,

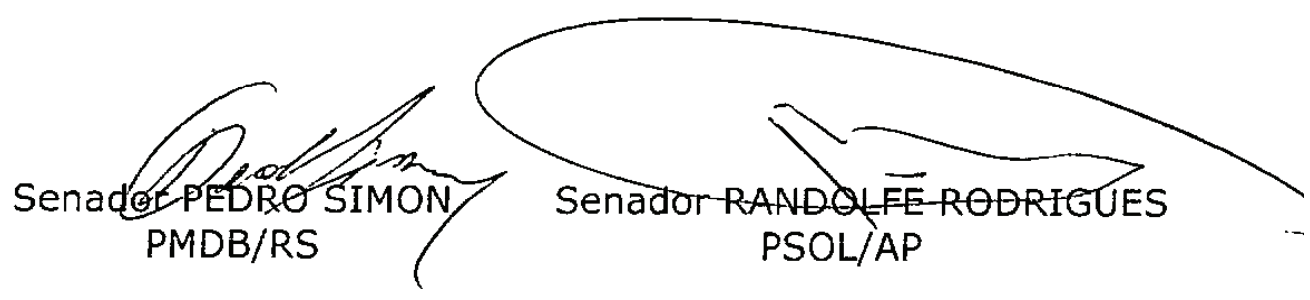




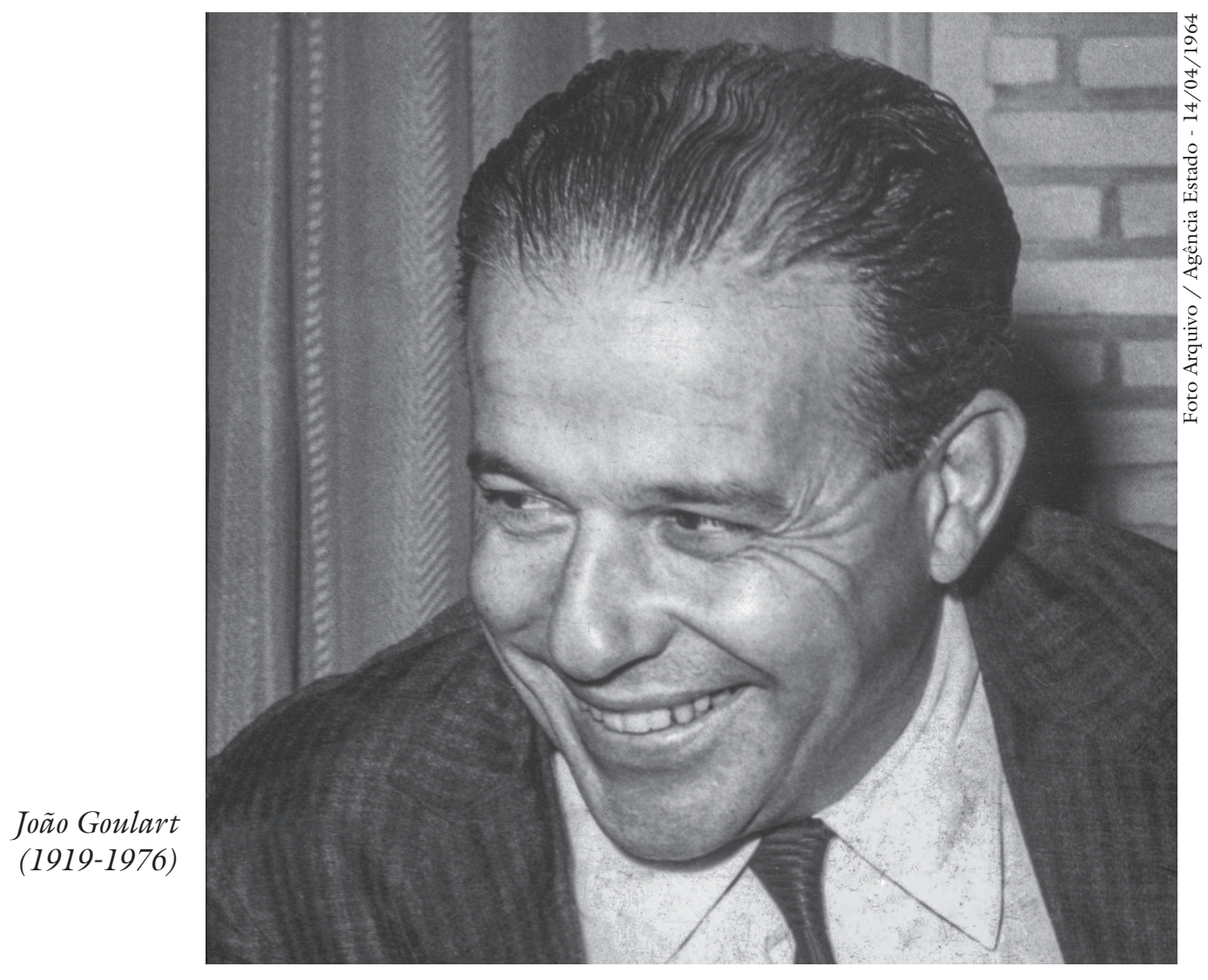

\section{Senado Federal}

Subsecretaria de Informações

Faço saber que o Congresso Nacional aprovou, e eu, Renan Calheiros, Presidente do Senado Federal, nos termos do parágrafo único do art. 52 do Regimento Comum, promulgo a seguinte

\section{RE S O L U Ç Ã O N 4, DE 2013-CN}

Torna nula a declaração de vacância da Presidência da República efetuada pelo Presidente do Congresso Nacional durante a segunda sessão conjunta de 2 de abril de 1964.

O Congresso Nacional resolve:

Art. $1^{\circ}$ Declarar nula a declaração de vacância da Presidência da República exarada pelo Presidente do Congresso Nacional, Senador Auro de Moura Andrade, na segunda sessão conjunta, da quinta legislatura do Congresso Nacional, realizada em 2 de abril de 1964.

Art. $2^{\circ}$ Esta Resolução entra em vigor na data da sua publicação.

Congresso Nacional, em 28 de novembro de 2013

\section{SENADOR RENAN CALHEIROS}

Presidente do Senado Federal 